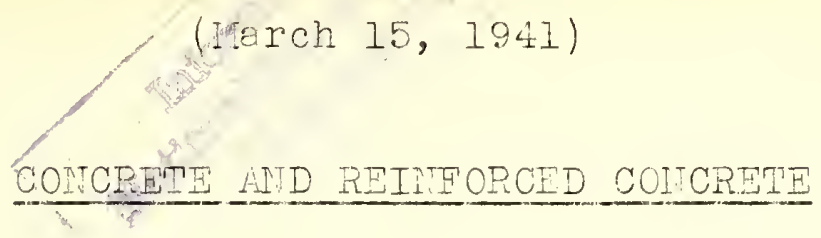

Publications by liembers of the Staff of the lational Bureau of Standards, together ith a list of Federal Specifications.

CONTINTS Page.

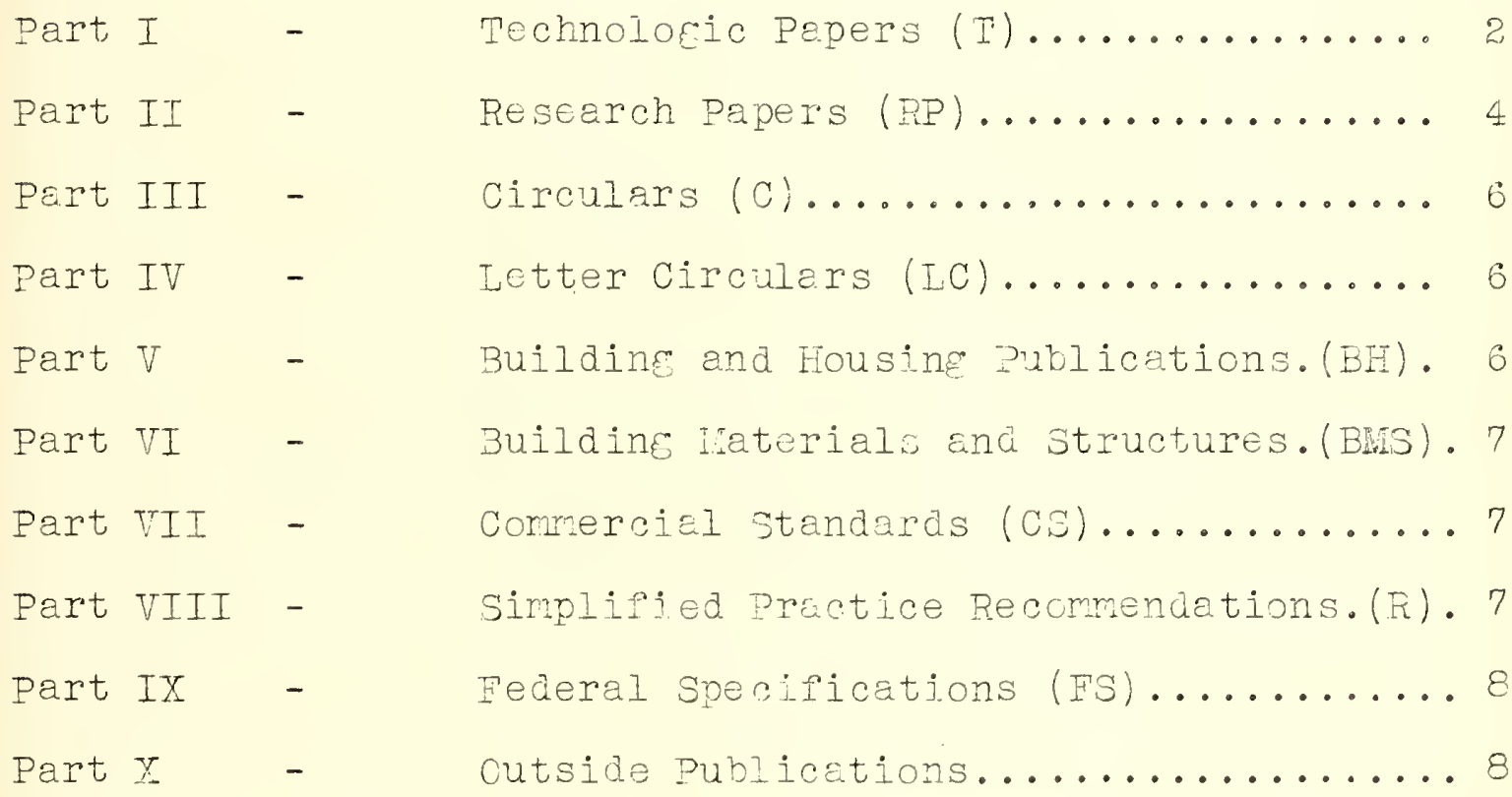

\title{
GEITERAT INEORIIATIOIJ
}

Some of the publications in this list have apreared in the revular series of oublications of the Bureau and others in various scientific and technical joumals. Unless specifically stated, papers are not obtainable from the ITational Bureau of standards.

There the price is stated, the publication can be purchased from the Sunerintendent of Documents, Government Printing office, Wasnincton, D. C. The prices quoted sre for delivery to adaresses in the United States and its territories and possessions and in certain countries wich extend the franking privilege. In the case of ail other countries, one-third the cost of the publication should be added to cover postace. Remittances should be riade either by coupons (obtainable from the superintendent of Documents in sets of 20 for $\mathrm{kl} .00$ and good until usea), or by check or money order payable to the "Superintendent of Documents, Government 
Printing office" and sent to him "ith order. Letter circulars are obtainable, without charke, from the Bureau. Publications mar'sed "op" are out of print, but, in Eeneral, may be consulted at technical libraries.

For papers in other scientific or technical journals, the name of the journal or of the orsanization publishing the article is fiven in abbreviated form ith tie volume number (underscored), nare, and year of publication, in the order named.

Serial letters are used to desinnate the several series of Bureau nubilcations:

$m=$ "Mechnologic paper." Ml to T370. This series
was superseded by the "Bureau of Standards
Journal of Research" in 1928.

$\mathrm{RP}=$ "Research paper." These are reprints of articles topearing in the "Bureau of Stanciards Journal of Research" and the "Journal of Research of the rational Bureau of Standards, " the Iatter bein the title of this perioaical since Tuly 1934 (volurie 13, nurnber 1).

BH= "Building an Housin" publicetion.

BNS="Building laterials and structures" publication.

C = "Circular."

CS $=$ "Comercial Standara."

LC = "Letter Circular."

$R=$ "Simplified Practice Recomrendation."

Circular c24 and sunplements, the coiplete list of the Burecu's buhlications (1901-1930), is sold by ths superintendent of Documents for 55 cents. Announcerent of new publications is made eacli month in the Technical. News Bulletin which is obtainable by subscintion at 50 cents per year.

\section{PART I. - TLCINOLOGIC PAPES}

The strength of reinforced concrete beams, (first series). R. L. Humphrey and L. F.

Series Price Losse. mech. Päp. BS I, (1910-12). 


\section{PAPT I. - TECHEOEOGIC PAPERS (Continued)}

Series Price

Tests of the absorptive and pemeable proper$\mathrm{T} 3$ $\mathrm{OP}$

ties of portland cement mortars and concretes,

torether with tests of damporofin and vater-

proofing compounds and materials. K. J. líg

and P. H. Bates. Tech. Pap. BS I, (1910-12).

The effect of high-pressure steam on the crush-

ing strentin if por land cement and concrete.

R. T. Tis? Tech. PA. BS I, (1910-12).

Action of the salts in alkali water end sea water Il?

on cement. P. 㳩. Bates, A. J. Phillips and

R. T. Tig. Tech. Pap. BS 2, (1912-14).

Electrolysis in crnozete. E. B. Rosa, B. McColiurn Tl8 and 0 . ¿. Peters. Tech. Pap. BS 2, (191;-14).

strength and other proverties of concretes as

558

OP

affected by materials and methods of prepara-

tion. R. J. Tie, G. M. Tilisiams and E. R.

Gates. Tech. Pap. BS

Durability of' stucco and plaster construction.

I70

$\mathrm{OP}$

R. J. Tie, J. C. Pearson und I'. E. Imley.

Tech. Pap. BS $7,(1916-17)$.

Tests of bond resistance between concrete and

steel. H. A. Slater, M. M. Kichart and

G. G. Scofiela. Tech. Pep. BS 14, (1920-21)

Pouring and pressure tests of concrete. H. H.

Slater and A. M. Goldbecl. Mach. Dep. BS I4,

$(1920-21)$.

Iffect of repeatea reversals of stress on double-

T182.

$O P$

reinforced concrete bears. T. H. Slater, G.A.

T173 CP

Smith and H. P. Túlier. Tecl. Pan. BJ I4,

$(1920-21)$.

Fire tests of building colurins. S. I. Ingerg,

T184 $75 \varnothing$

H. K. Griffin, . C. Robinson and R. E。 Tilson.

Tech. Pap. BS 15, (1921).

Tests of a hollow tile and concrete floor siab reinforced in two directions. H. Slater, A. Hagener and G. P. Anthos. Mech. Pap. BS $16,727(1921-22)$. 


\section{PART I. - TECHNOLOGIC PAPERS (Continued)}

Tests of hesvily reinforced concrete slab

bearis. 'T. H. Slater sna F. B. Seely.

Tech. Par. BS 17, 297 (1922-24).

Ioading tests of a hollow tile anà reinforced

I236

$O P$ concrete floor of Arlington Building, Washingtion, D. C. I. T. Larson anà S. I.

petrenío. Tech. Pap. BS 17, $405(1922-24)$.

Tire resistince of concrete columns. T. H. T272 $25 \not 6$

Hull an? . I. Inciverg. Tecir. Pay. BS 18, $635(1924-5)$.

rests of hollow tile an concrete slabs reinforced in one direction. D. E. Parsons and A. I. Stan . rech. Pap. BS 19, 455 $(1924-25)$.

Durability of cerent lrain tile und concrete 1307

in alkali soils; fourth progeress report

(1923). G. I. Tilitiams and I. Furionø.

Tech. Pap. BS 20, $191(1925-26)$.

Shear tests of reinforced concrete beams.

$\mathrm{T} 314$

T. Slater, A. R. Lord and $\mathrm{T}$.

7iprodt. Techi. Pap. BS 20, 387(1925-20).

\section{PARI II - RESEATCEI PHPERS}

Iest of the effect of brackets in reinforced

$P ? 9$

concrete ricia frares. F. E. Richart.

BS T. Resecrci I, $189(1928)$.

Tests of comnosite beams and slabs of hollov tile ana concrete. D. I. Parsons and

$R P I 81$

A. H. Stanf. BS T. Research 4 , $2 I \equiv(1930)$.

The ph:sical properties cf cast stone. T.

RP3E9

54

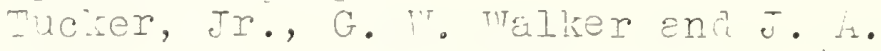
Swenson. BS J. Research 7, $100 \dot{7}(1931)$.

Tests of intecral and surface waterproofinss for concrete. C. H. Tumser. BS J.

Rescarch 7, $1147(2331)$.

Areas and tensile nrope: ties of zeformed

$R \supset 480^{\circ}$

concret -reinforcernt bars. H. H. Stans,

R. I. Siveetman and $C$. Goum. BS J.

Researcir $\subseteq$, $509(193 \mathrm{i})$. 


\section{PAPT II - PESEARCH PAPERS (Continued)}

Series Price

Clay in concrete. D. A. Parsons. BS J. Research 10, 257(1933).

Tests on a reinforced-concrete arch of

RP609

OP

the frlington liemorial 3ridee.

RP529

C. C. Fishbum and J. I. Magle.

BS T. Research 11, 567 (1933).

Ixperiments on exterior waterproofing

RP771

materials for rasonry. D. Tessler.

J. Pesearch IMBS 14, 3.17 (1935)。

Effect of granulometric composition of cement

RP777

on the properties of pastes, mortars and

concretes, T. Artliur Swenson, Lacey $A$.

Magner and George I. Pisman.J.Research

NBS 14, 419(1935)。

Effect of calciurn chloride on portland cerents

and concretes. Paul Rapp. T. Research

RP782

NBS 14, 499(1935).

Behavior of tigh-eerly-strength cer-ent

RP799

concretes and rortars under virious

temperature and humidty conditions.

Louis Schuman and Edvard A. Pisapia.

J. Research TIB. 14, 723(1935).

Some tests of steel columns incased in concrete.

RP873

Ambrose $H$. Stang, Herbert I. Thittemore and

Douglas T. Parsons. J. Research IBS 16,

$265(1936)$.

Effects of particl prehydration and different

RP887

curing terneretures on some of the proper-

ties of cement and concrete. F. B. Hornjbrook,

G. I. Talousek, and C. H. Tumper.

J. Fesearch NBS 10, 4e7(1930).

Effect of temperature on the stress-defomation

EP970

of concrete. Arthur U. Theusr. J. Research NBS 18, 295(1937).

A stuay of vibrated concrete. J. Tucker Jr.,

G. L. Pimen, F. A, Pisapia and J.S. Rogers.

J. Research NTBS 19, 575(1937). 


\section{PADT II - PESE PCE PPERS (Continued)}

Series Price

A nortable apparstus for reasurine vibretion EPII01 10\%

in fresh corcrete. G. I. Pi man, F. B.

Iorn brook and J. S. Dogers. J. Feseareh ITS $20,797(1938)$.

Concrete as a protective material amainst high- RDll55 voltare rerga. Goré Sirser, Lauiston s.

Tayior, and Aryd L. Chariton. T. Research

TPS 21, $783(1938)$.

A portoble anomatus for detemining the rélative RPI252

vear resistance of concrete filoors L.

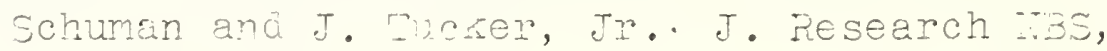
$23,549(1938)$.

An lication of vibrotors for reasuring mortar consistency ani febriceting ronter cubes

FP127.3 10ф

F. I. Blaine and, Fucier, Jr. J. Research

IVBS 24, $103(1240)$.

Fethod for detemining the roisture conition

P.P1334

$5 \not$

in harajed corcrete. G. F. Gevise and

T. Tucker, Tr. T. Research 133 EE, $403(2940)$.

\section{PART III - CIEOULAES}

Properties and manufacture of concrete buildin units. Cir. ES, (1920).

C.304

Stucco investiestions at the Bureau of C3II

Standaras ith recommendatione for

ncrtiend cereno stucco construction.

Cir. BS, (1525).

$$
\begin{aligned}
& \text { PART IV - DAPR CIRCUIARS } \\
& \text { (EReE on Application to Buneau) }
\end{aligned}
$$

Acja-proce patings for crncrete surfaces.

Let. Cir. 3o, (Tebruerr 1?, 1803).

$I C \leq 2$

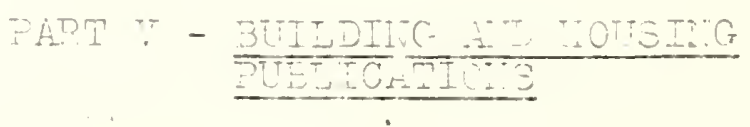

Recorrende a ritiding code requirerents for vorik - Bra ing stresses in builain raterials. (1920). 


\section{PART VI - BUILDIIG MATERIALS AIT STRUCTURES}

Structural properties of a "milecrete" ploor construction sponsored by rilecrete Floors,

Series

Price

Inc. I. I. Thittemore, A. $y_{\text {. Stang, and }}$

C. C. Fishburn. (1939).

Structural pronerties of "Twachtman" constructions for valls and floors sponsored br Connecticut Pre-Cast Builaings Corporation. II. L. Thittemore, H. I. Sting, and D. E. parsons. (1939).

Structural properties of "ielson Pre-cast Concrete Foundation" well construction sponB. + SSI $10 \notin$

BI:S20 $10 \not$ sored by the lielson Ccment stone Compary, Inc. H. L. mitteriore, it. H. Stang, and C. C. Fishburn. (1939).

Structural vroperties of a wall construction of "Thep Concrete Hall Units" sponsored by Knap America, Inc. H. I. Thitterore, s. I. Stang ant C. C. Fishburn. (February 1940).

Structural properties of "Tilecrete Type $\mathrm{H}^{\prime \prime}$ floor construction sponsolea by the pilecrete Corporation. A. I. Steng and D. I. Parsons. (June 1940).

Structural properties of to nonreinforced I'onolithic concrete vall constructions. A. I. Stang and D. E. Parsons. (october 1940).

Structural nroperties of a mrecast joist concrete floor construction syonsored by the BITS62 Portland Cerent Association. II. I. mitterore, A. H. Stang, and D. E. Parsons. (cetober 1940).

BiTS26 10ф

BiT $540 \quad 10 \notin$

BI:S51 10\%

Bi:S61 10\%

\section{PAET VII - COITICIAL STALAEDS}

Series Price

Cast stone, colors an finishes Ior

$53-35$

$5 \not$

\section{PART VIII - SIPIIETED PRACTICE}

Steel reinforcing bars. (1930).

R26-30 5q́

Concrete building units (block, tile ana brick) R.32-38 


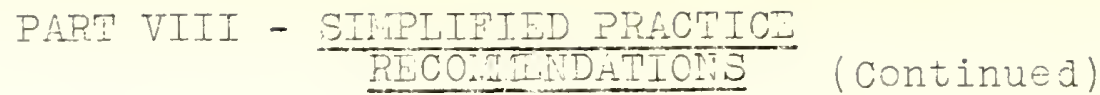

Series Price

Forms for concrete joist construction foors. R87-32 OP $(1932)$.

wire diameters for mineral aferegate produc- Fil47-3.3 $5 \not$ tion screens. (1933).

Coarse afgregetes (crushed stone, erovel, Fl63-39 and slag) $\cdot(1939)$.

\section{PART IX - EEDIRAL SPECIFICAIIOIS}

The specifications listed belor. are issued b: the Federal Specifications Erecutive Committee, Procurement Division, Federal Tarchouse, Washington, D. C. Copies may be secured from the suprintendent of Documents, Government Printing Office, this city, at the prices indicated.

Bars; reinforcement, (for) concrete.

$\frac{\text { Series }}{22-B-71 a} \quad \frac{\text { Price }}{5 \phi}$

Bases; metal; (ror) plaster end stucco

$Q 6-3-101 \mathrm{C}$ construction.

Sieves: standard testino.

$F R-3-366$

$5 \not$

Argregates; ( $f \circ I^{\circ}$ portland cement concrete. SS-H-68I Brick; concrete. $\mathrm{SS}-\mathrm{B}-663$

cements, hydrallic, general specifications. SS-C-158 (rethods for samplino, inspection and testinr).

cement; masonry.

cerrent; portland.

cement; portland, hish-early strength.

$S S-C-181 b$

$S S-C-191 a$

$\mathrm{SS}-\mathrm{C}-201$

cement; portland, moderate-heat-ofhardening.

$S S-C-200^{\circ}$

Cement; portland, pozzoland.

$\mathrm{SS}-\mathrm{C}-208$

$5 \not$

Cement; portland, sulphate-resisting.

$\mathrm{SS}-\mathrm{C}-211$

$5 \not$

$S S-C-621$

Concrete-TJits; masonry, hollow.

Stone; architectural, cast

$\mathrm{SS}-\mathrm{C}-721$

Pipe; cement-asbestos.

$S S-P-351$

Pipe, concrete; non-pressure non-

$S S-P-371$ reinforced and reinforced.

\section{PAIT $X-$ CUTMIDE PUBLIC IPIOIS}


PART X - OUTSIDE PUBLICATIOIS (Continued)

or in some cases may be purchased directly fror the publishers:

Action of the salts in alkali vater and sea water on cement.

R. J. Mig and P. H. Bates. J. Franizin Inst. Joumal

of the Franklin Institute, 20tin \& Parway, Philadelphia,

Pa.), 175, 65(1913).

Reinforcea concrete slabs. M. H. Slater. Proc. Am. Soc. Testing Materials (American Society for Testing Naterials, 260 South Broad st., Philadelphia, Pa.), I3, 874(1913).

Use of the strain gage in the testing of materials. T. H. Slater and I. F. Ioore. Proc. Ar. Soc. Testing lieterials, 13, $1019(1913)$.

Properties of portiand cerrent having a high jigo content.

P. H. Bates. Proc. An. Concrete Inst. (American Concrete Institute: '7400 Secona Blvd., Detroit, Ifich.), 10, 470(1914).

some further results obtained in investigations of the properties of portland cement having a high ligo content. P. H. Betes. Proc. Mr. Concrete Inst., 11, (1915).

The effect of fine rindins and a higher $\mathrm{SO}_{3}$ content upon the physical properties of portland cenent. P. H. Bates. Proc. Am. Soc. Testinf laterials, 15, Part II, 126(1915).

What is the trouble vith concrete in seavoter? R. T. Wig and Levis P. Ferouson. Series of five articles in Fre. NewsPecord (rocraw-Hill Publishing Co., Ino., 330 Vest $42 d$ St., Nev York, NT. Y.), Sentember 1817.

Tests of stucco. J. C. Pearson. Proc. M. Concrete Inst., 14, $109(1918)$.

Fire tests of concrete column. A. Hull. Proc. Am. Concrete Inst., 14, 138(1918).

Tentative report on desion of reinforced fypsum. H. Slater. Proc. Ar. Soc. Testin Ifaterials, 19, Part II, $348(1919)$.

Cenents producing quick hardenirg concretes. P. H. Bates. Proc. Am. Soc. Testing liaterials, 19, Part II, 429(1919).

Proportioning of concrete. G. H. Willians. Proc. H. SOc. Testine Materials, 19, Part II, 476 (1919).

Elasticity of concrete. G. Mr. Williams. Proc. Ar. Soc. Testing Materials, 19, Part II, 594(1919). 


\section{PART Y - OUTSIDE PUBLICATIONS (continued)}

Structural laboratorr investigations in reinforcte concrete made by Concrete Ship Section, Emerency Pleet Corporation. . H. Slater. Proc. An. Concrete inst., 15, 24(1919).

Tests of concrete tanks for oil storage. J. C. Pearson and G. is. Srith. Proc. Mr. Concrete'Inst. (Huerican Concrete Institute, 7400 Second Blva., Detroit, Iiich.), 15, 150(1919).

Tests of two recent theories ror proportioning concrete. G. Tilliams and Vatson Davis. In . Mews-Record (IicGrav-Hill Publishing Co., Inc., $330 \mathrm{H}$. 4and St., IEU Iork, I. Y.), Tune 12, 1919: Suhsequent discussions unc cortributions, Eng. NTevs-Record, August 14, 1919 and April 2\%, 1920.

rests of plain end reinforced grosum bears. T. H. Slater and G. P.Anthos. J. Vestern Soc. Engrs. (Vestern Society of Encineors, II2l Dobson Jt., Evanston, Illinois), september 1918.

Fire tests of concrete colums. H. Hull. Proc. im. Concrete Inst., 16, 20(1920).

Tier developrents in surface treated concrete and stucco. ¿. C. Pearson and T. J. Eariey. Proc. Am. Concrete Inst., 15, $70(192,0)$.

Compressive strength of concrete in flexure. TT. A. Slater and R. R. 7inprodt. Proc. Im. Concrete Inst., İ, 130(1920).

some determinations of the stress deformation relations por concrete under repeated and continuous loalings. G. I.. rilizams. Proc. fm. Soc. Testine liaterials (Hmerican Jociety for Testine iraterials, 200 South Broad st. , Philadolphia, Pa.), 20, Part II, 233(1920).

Modulus ot elasticity of concrete. G. li. piliams. Proc. Ar. Soc. Meting ratuials, 20, part II, soz(1920).

How can laboration tests of concrete ratirials ke made of greater velus to the field encineer and contractor' C. L. Tiliians. Concrete (Concrete Jublishins Co., 400 . liadison st., Chicago, Tllinois), 16, 184, April ig:o.

Flovability of concrete ard its neauremunt by reans of the flow

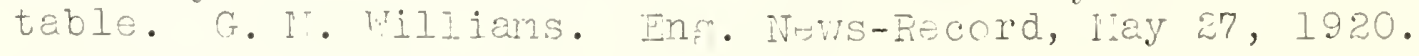

Reinforcement for diaconal tension. N. Slater. Concrete, I?, Ausust, 1820 .

Further testa of concrete tanks for oil storage. G. H. Srith. Proc. Am. Concrute Inst., 17, 22(1921). 


\section{PAPT X - OUTSIDE PUBLICFTIONS (Continued)}

Lessons in fire resistance from the Frankford fire. U. A. Hull. Proc. Am. Concrete inst., 17, 205(1921).

moments and stresses in slabs. H. M. Mestergaard ánd $H_{\text {. }}$ slater. Proc. Am. Concrete Inst., 17, 415(1921).

Time of set of concrete. Tatson Davis. Proc. Am. Soc. Testing Materials (American Society for Testing Nateriels, 260 South Broad St,., Philadelphia, Pa.), 2I, Part II, 995(1921)。

Discussion on tentative specifications for concrete and reinforcea concrete. A. Slater. Proc. Am. Soc. Civil Engra. (American society of Civil Encineers, $33 \mathrm{~V}$. 39 th st., New York, IT. Y.), septernker 1821.

Concrete by strength - Austrian specificatjons, transiations, and comrerts. A. Slater. Concrete (Concrete Publishing Co., $400 \mathrm{H}$. radison St., Chicago, Illinois), 19, 231, Decerber 1921.

Effect of hydrated line on the strength and flow of concrete. ". Enley. Proc. An. Soc. Testine Haterials, 22, Part II, $284(1922)$.

Girderless flooria in Malmo; Sweden - Translation and comments. I. Alater. Concrete, 20, 204, June 12i2.

Alkali ettack on concrete roads and building brick - A study of disintegration in Glenn County, California. Irvine Furlong. Eng. Mews-Record (Inchaw-Hill Publishine Co., Ine., 330 t. 4ind St., Nev York, N. Y.), July 13, 1922.

mat quality of concrete block should become standard? J. C. Peirson. Concrete, 21, 135, Tovernber 1922.

Tests to detemine aistributjon of stressea in flanges of T-beams. A review of test result a and building" specifications. M. A. Slater. Concrete, 21, 145, roveriber 1922。

A penetration test for the workability of concrete mirtures with particular reference to the effects of certain powdered admixtures. J. C. Parson and F. A. Iijtchcock. Proc. Ar. Soc. Testinglaterials, 23, Part II, $276(1923)$.

An interesting case of dangerous aggregate. J. C. Pearson ard. G. F. Loumlin. Droc. Am. Concrete Inst. (American Concrete Institute, $740 C$ Second BIVa., Detroit, Iich.), 19, I42(1923). Thouphts on concrete houses. J. C. Pearson. Proc. Concrete Inst., 19, $167(1923)$. 
Irundation methods fom reasurement of sand in maing concrete. G. j. Jrith and ... Slater. Proe. Am. Concrete Inst., $19,222(1923)$.

Tcononic value of adritures. T. C. Pearson end Frank f. Hitcheock. Proc. Ar. Concrete Inst., 20, $312(1924)$.

control of concrete for University of Illincis Stadium. slater ord R. I. Brovin. Proc. Mm. Concrete Inst., 20, 2.03 $(1924)$.

Field tests of concrete used on constructior rork. r. SIater and Stanton Thiker. Proc. Ar. Concrete Inst. (Hmerican Concrete Institute, 7400 second Bivä., Detroit, ïich.), 20, $420(1924)$.

Stucco invegtigationi of the Bureau of Standards. J. C. Pearson. Proc. ol Builing Cificíals conference, Io, 143(1924).

Accelerators for concrete. T. C. Pearson. Conorete (Concrete Puhlishing cr., 400 Indison Atrue, Cilcago, Ininois), 24, 33, Januery 1324 .

Crazire on cement oroducts. P. Bates. Proc. m. Concrete Inst., 21, $120(1325)$.

Repolt on field tests of concrete used in construction rork. ". H. Slater and Stenton Waker. Proc. rit. Joc. Civil Dngrs. (American Society of Civil Enmineers, 33 \%. 3ith St., IJev Vork, IT. Y.), 51, 1, Janusry 1925.

Tests of bond resistarce in rejnforced concrete bearis - rmanslétion end discussicr. r.... Slater. Ene. Iitws-iecorá

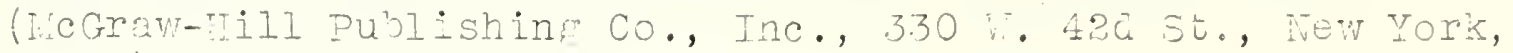
IT. Y.), Tune 25, 1955 .

Fine grindin of cernt increases strengti oi concrete. Icrris Temin und T. High. Concrete, 27, 47, september 1925.

Close water control importent in alumina cement concrete. P. E.

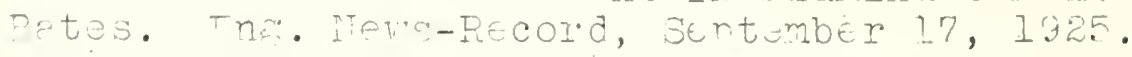

Whet th. Purvau of otendards is Joink to solve rang nroblers relatirg to concute. Frank A. Iitcheock. Conercte, 7 , 30 , ortober $19 \geqslant 5$.

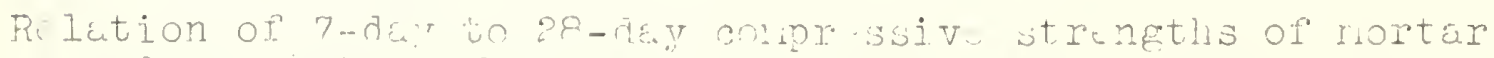
and roncrote. ‘. Slater. Proc. In. Concrete Inst., 2 , $4.37(19: 6)$. 


\section{PART X - OUTSIDE PUBTICATOISS (Continued)}

Use of sulphur in rendering concrete drain tile resistant to attack or alkali. P. H. Bates. Ind. ¿ ing. Chem. (Industrial and Ingineering Chemistry, Fills Bldg., Washington, D. C.), Harch 1926.

Long-time tests of high magnesia cements. P. H. Bates.

Proc. Am. Soc. Testinf laterials (American Society for Testing ltaterials, 260 South Broad St., Philadelphia, Pa.), 27, Part IJ, 324(1927).

Portland cement in concrete engineering. R. I. Bogue. Proc. Am. Concrete Inst., 23, 355(1927).

Why time is $a f$ ctor in the study and use of cement. P. H. Bates. Proc. Am. Concrete Inst., 23, 436(1927).

Adhesion of plaster and stucco to hollow building tile. T. A. Murray and H. D. Poster. Ari. Architect (Hearst Magazine, Inc., 572 kadison Avé., NEW Zork, I. Y.), 132, 839, December 20,1927 .

A study of sone netrods of measuring vorkability of concrete. George A. Smith and Georse Conehey. Proo. Am. Concrete Inst. (American Concrete Institute, 7400 Second BIVd., Detroit, Bich.), 24, 24(1928).

Cement as a sector in the workability ol concrete. P. H. Bates and J. R. Dwyer. Proc. in. Concrete Inst., 24, 43(1928).

Notes on the progress of sone sturies of the crazing of portiand cement mortars. P. F. Bates and C. H. Jumper. Proc. Am. Concrete Inst., 24, $179(1928)$.

Some features of the testing of Stevenson Creek arch dam. V. A. Slater. Proc. Am. Concrete Inst., 24, 273(1928).

Bond between concrete and hollowtile. J. C. Oleinik. Ing. and Contr. (Engineering and Contrscting, Gillette Publishing Co., 401 ". Madison St., Chicago, Illinois), 57, 19, January 1928.

Report of tests on Stevenson Creek Dam. A. Blater. Proc. Am. Soc. Civil Ingrs. (American Society of Civil Engineers, 33 i. 39th st., New York, i. Y.), May 1928.

Tension, bend and jrmact tests on reinforcerent bars. V. A. Slater and G. A. Smith. Proc. Am. Soc. Testin lateials (American Society for Testing Ifaterigls, 260 South Broad St., Philadelphia, Pa.), 29, part II, 183(1929). 


\section{PART X - OUTSIDE PUBLICEIONS (Continued)}

Influence of mineral composition of aggregates on fire resistance of concrete. S. H. Ingberg. Pro. im. Soc. Mestinf ifaterials, 29, part II, 824(I:29).

The pliysical pronerties of commernial cast stone. J. Tucker, Jr. and G. '. Maliet. Proc. Ari. Concrete Inst., 25, 501(1929).

Discussion of paper by searcy B. Slack on "The behavior of a reinforced concrete arch durine construction." D. E. Parsons. Proc. Am. Soc. Civil Engrs., 2279, Noveriber 1929.

Hish strength, high early strength and witerproof concrete. P. Fates. Engrs. and Eng. (Enpineers and Engineering Ceased publination with Tol. 49, Herch 1932), 46, 177, TUly 1929.

The relation betveen the strengths of cerents develoved by mortar specimens ano concrete specimens. J. R. Dwyer anà P. i. Bates. Proc. Mr. Soc. Testing Faterieis, 30, Part II, 598(1930).

Some properties of hirh alurina cerient from six countries. P. H.

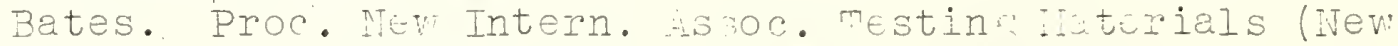

International fasociation for Postin irterisls, Leonhardstrasse 27, Zurich, Switzeriand), Group B, 210(1930).

Cerent and concrete (Chapter mVIII, Annusl Survey of srerican Chemistry, 1930). John Tucler, Ir., Annual Jurvej k. Chem. (Annual Survey of American Chemistry, National Research Council, Washington, D. C.), Lay 1931.

The selection of durable aggregates for concrete. "K. Temin, J. Tucker, Jr., and Vard Pirran. Fock Products (Tradepress Prolishing Corp., 205 T. Vacker Drive, Chicaé, Illinois), 34, 37, August I, 1931 .

The physical properties of cast stone. J. Tucker, Ir., G. Walker and. Arthur Swenson. Proc. Ar. Concrete inst. (Emerican concrote Institute, $74_{x} 00$ Seconả Biva., Detroit, michifan), 28, 243(1831); ISO 30 T. Research 7, 1037(1831) RP389.

Tests of interral and urface wateroroings for concrete. C. H. Tumer. Pror. Am. Concrete Inst., 29, 2C9(1931); also BS J. P.esearch 7, 1147(1931), RP394.

Volume chanes of mpsum fiber noncrete. F. F. Incidie and F. I. Itarsh. Pook Products, 35 , irreil ab, 1.32.

Tests of resnager rinees. D. E. Parsons una A. H. utan Proc. Ar. Concrete Inst., 31, 304(1935). 


\section{PART X - OUISIDF PIJBIICAIIOIS (continued)}

Factors of workability of portana cement concrete. W. H. Herschel and E. A. Pisapia. Proc. H. Corcrete Inst., 32, $641(1936)$.

Effect of departure from plareness of bearing surfaces on the comnessive strength of 2-in. rortai cubes. J. R. Dwyer. Proc. Am. Soc. Testing ifoterials (Arerican society for Testing Iaterials, 260 South Broad St., Philadelphia, Pa.) 36, Part II, 351 (1930).

An apparatus for deterrinin Yonn's nodulus of building materials by the dinamic rethod - F. B. Iornibrook. Bull. A.S.T.i. , Dec. 1939. 
